\title{
Die aanduiding van tyd in die boek Daniël
}

\author{
P.A. Verhoef \\ Dept. Ou Testament \\ Universiteit van Stellenbosch \\ STELLENBOSCH
}

\begin{abstract}
The study of the relevant terms concerning 'time' in the book of Daniel, led to the following conclusions:

It is remarkable how often reference is made in this book to 'time', - time in its different aspects of "point of time", "duration of time", and "units of time" (cf. Louw \& Nida, 1988:628-629). Almost every one of the most important Hebrew and Aramaic terms in this regard is used.

This phenomenon is evidently of paramount importance for both a correct translation and a sound exegesis of the book. Translations should refrain from de-syntacticizing words according to a 'concept ' method, without due regard for the nuances of meaning in various contexts. The exegesis should also pay the necessary attention to the historical and the eschatologicalapocalyptic perspectives contained in the relevant terms.

The great emphasis placed on "the time of the end", in terms of ppand עip, corresponds remarkably with the divine periodization of historical and eschatological epochs in the Qumran-literature, and in the Rabbinic usage of these terms. This simularity of usage seems to endorse the point of view that the book of Daniel originated in the second century B.C.

A theologically significant point of view is that "time" in the book of Daniel is perceived throughout of as being appointed by God. This is evident from the usage of the term 7 D. and the meaning of the Aramaic words ID? and עִ עִ
\end{abstract}

\section{Tyd en ewigheid}

Enigiemand wat hom in die onderwerp tyd en ewigheid wil verdiep, sal gou besef dat hy met ' $n$ brandnetelbos te doen het. Dit was die ervaring van filosowe en teoloë dwarsdeur die geskiedenis heen (vir ' $n$ uitvoerige bespreking van verskillende filosowe en teoloë se sienings, kyk Spier, 1953:7-98). Augustinus het byvoorbeeld gesê: "As niemand my vra wat tyd is nie, weet ek dit. As ek dit 
moet verduidelik, weet ek dit nie.' Die naaste wat hy aan 'n oplossing vir hierdie probleem kon kom, was om te sê dat die uitgangspunt in die Skrif is dat 'ewigheid' alleen aan God toekom, en dat die 'tyd', deur God geskep, by die skepsel hoort (uit sy Confessiones, 11.13, aangehaal by Spier, 1953:5, 14-16).

Spier vestig die aandag op agt kenmerke van 'tyd': opeenvolging, duur, verandering, rigting, fase, homogeniteit, gelyktydigheid en dimensie. In die tydstroom is daar 'n 'opeenvolging' van momente. Die tydstroom strek uit oor langer of korter periodes, en veronderstel dus 'duur'. Vir die naïewe ervaring is tyd en 'verandering' dieselfde: tyd is nie sonder verandering en omgekeerd is verandering nie sonder tyd nie. Die tyd het ' $n$ 'rigting' wat vir plante, diere en die mens onomkeerbaar is. Die 'fases' of verskyningswyse van die kosmiese tyd is verlede, hede en toekoms: die verlede is verstarde tyd, die hede is aktuele tyd, en die toekoms moontlike tyd. Die tyd is op al sy punte 'homogeen', dit bly in wese dieselfde. In die tyd is daar ook 'n aspek van 'gelyktydigheid': momente van die tyd is nie net vóór en ná nie, maar ook gelyktydig. Daarby is daar ook verskillende 'dimensies' of lae in die tyd (Spier, 1953:104-117).

Ons weet dat 'tyd' ' $n$ begin het, maar ' $n$ interessante vraag is of dit uiteindelik sal ophou? Wat gebeur met 'tyd' die dag as ons sterf? Wat gebeur daarmee by die wederkoms van Christus? Op die eerste vraag sou ons kon antwoord: as ons sterf, betree ons die 'tussentoestand', wat 'n begin én 'n einde het, wat moontlik in tydsbesef deurleef sal word. Ook by Christus se wederkoms, dus op die nuwe aarde, sal daar 'tyd' wees - tyd wat gevul sal word met geseënde bedrywigheid, waarin God gedien en geprys sal word. Dit is die volheid van die 'ewige lewe', wat altyddeur voortduur, wat nooit tot 'n einde kom nie. Die ewige lewe bly egter kreatuurlike lewe, wat nooit vergoddelik word nie, dus ook nooit in absolute sin 'verewig' nie: dit sal 'n kreatuurlike 'ewigheid' wees, 'n tydsuksessie sonder einde (vgl. Spier, 1953:126-127).

\section{Geen teorie oor tyd nie}

Wanneer ons met hierdie 'wyshede' na die Skrif toe gaan, stuit ons op die probleem dat die Skrif, en met name die Ou Testament, nêrens 'n teorie of beskouing oor 'tyd' het nie (vgl. Smick, 1976:1710: "The Hebrews were not avid seekers after impersonal causes, and time as an abstract concept was outside their interest"). Die Ou Testament - om my net tot hierdie deel van ons Bybel te bepaal - het wel 'n verskeidenheid woorde wat vir die aanduiding van 'tyd' gebruik word, maar nêrens word spesifiek verduidelik wat ons onder 'tyd' moet verstaan nie. Daarby kom nog dat die dae van die metodologie van die sogenaamde 'etymologizing school', veral sedert die verskyning van $\mathrm{C}$. von Orelli se boek Die hebraïschen Synonyma der Zeit und Ewigkeit genetisch und sprachvergleichend dargestellt (1871), vir goed verby is (vgl. De Vries, 1975:31, en veral 335-337). Die aksent lê tereg op die gebruik van woorde in hulle konteks, en juis in hierdie 
opsig is dit nie altyd maklik om die presiese betekenis van 'n woord vas te stel nie.

'n Studie van die aanduiding van 'tyd' in die boek Daniël lewer die verrassende resultaat dat, ten eerste, die meeste terme vir 'tyd' in hierdie boek voorkom, en ten tweede, dat die gebruik van sommige van hierdie terme meer met dié van die Qumrangemeenskap en van die latere Rabbyne ooreenkom.

\section{Eenhede van en terme vir 'tyd'}

Net soos die boek Esra, bestaan die boek Daniël ook uit 'n Hebreeuse (1:1-2:4a en 8-12) en 'n Aramese (2:4b-7:28) gedeelte. Hierdie twee gedeeltes bevat 'n wye spektrum van belangrike terme as aanduiding van 'tyd'. Behalwe die vier basiese 'eenhede van tyd': dag, week, maand en jaar, het die boek Daniël ook vyf Hebreeuse en vier Aramese terme wat vir die aanduiding van 'tyd' in aanınerking kom.

\subsection{Eenhede van tyd}

Ons let eers op die vier 'eenhede van tyd': dag, week, maand en jaar (vgl. Finegan, 1964:7-21 vir 'n omvattende bespreking).

\section{- Dag}

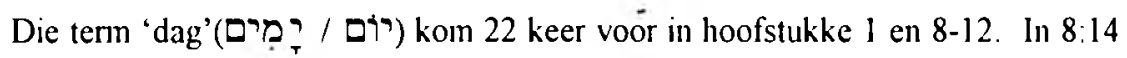
en 26 word die 'dag' onderskei in aande en oggende, waaruit ons kan aflei dat die dag destyds in die aand begin het (vir 'n bespreking van die begin van die dag, kyk Beckwith, 1971:218-227 en Stroes, 1966:460-475). As byvoeglike naamwoord het 'dag' in 'n aantal gevalle die betekenis van duur. Koning Nebukadnesar het bepaal dat Daniël en sy vriende 'n "daaglikse" (letterlik: 'n dag op dag') porsie van sy kos en wyn moet ontvang (1:5). Die proefneming moes "tien dae lank" duur $(1: 12,14)$; "aan die einde van die tien dae" was die resultaat verstommend (1:15). Dit was "die tyd" (letterlik: 'die dae') wat deur die koning bepaal is (1:18). By geleentheid het Daniël "lank" (letterlik: 'dae lank') siek gelê (8:27). Dag ontvang ook die betekenis van 'hede', 'vandag', in aansluiting by wat vooraf gebeur het $(9: 7,15$, vgl. 1933-vertaling). In die meervoud beskryf dit 'n bepaalde periode waarin ' $n$ besondere gebeurtenis plaasgevind het. Daar is sprake van "in daardie dae" = "drie weke van dae", dit is "drie volle weke" $(10: 2,3)$. Op die vier en twintigste dag van die eerste maand was Daniël by die Tigris (10:4). 'n Man met linneklere aan het aan hom verskyn en hom gerusgestel met die woorde: "... van die eerste oomblik af ... is jou gebede verhoor" (10:12). Hier kry dag die betekenis van 'n bepaalde tydstip. Die engel van die Persiese ryk het dié man een en twintig dae lank teruggehou (10:13). Die betekenis van dag in die sin van 'duur', blyk ook uit 11:20 en 23,12:11 en 12. Die koning van die noorde sal 
"binne enkele jare" (letterlik: 'dae') on die lewe gebring word (11:20). Die Siriese koning Antiogos Epifanes sal die verstandige leiers van die verbondsvolk "n tyd lank" (letterlik: 'dae lank') doodmaak (11:23). Die vervolging van die vromes onder die verbondsvolk sal 1290 dae lank duur, en dit sal goed gaan met wie geduldig bly "tot 1335 dae verby is" (12:12). Daniël moet aanhou "tot die einde toe" (letterlik: 'tot die einde van die dae') (12:13).

'n Belangrike gesigspunt in die boek Daniël is die eskatologiese gebruik wat van die term dag gemaak word. Daniël moes die visioen geheim hou, "want dit sien op die verre toekoms" (letterlik: 'op baie dae') (8:26). Een keer vind ons die

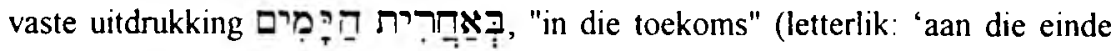
van die dae') (10:14) wat opgevolg word met die opmerking dat die visioen sien "op die tye" (letterlik: 'dae') wat kom (10:14).

\section{- Week}

In die boek Daniël word die week, as tweede eenheid van tyd, meesal in die sin van 'tydperk' gebruik. Hierdie betekenisnuanse van week kom veral voor in die moeilike gedeelte 9:24-27. Sewentig "tydperke" (letterlik: 'sewetalle') word vir die verbondsvolk en die heilige stad vasgestel $(9: 24)$. Gedurende dié tyd sal verskillende dinge gebeur. Vandat die opdrag gegee is om Jerusalem te herstel, totdat ' $n$ regeerder kom wat deur God uitverkies is, sal "sewe tydperke"(letterlik: 'sewetalle') verbygegaan het $(9: 25)$. Jerusalem sal daama "twee en sestig sewetalle" in moeilike tye opgebou bly $(9: 25)$. Aan die einde van hierdie tydperk sal 'n regeerder onskuldig doodgemaak word, en sal die einde kom soos 'n oorstroming (9:26). Die verdrukker van die verbondsvolk sal "vir een tydperk"('sewetal') 'n vaste ooreenkoms met die afvallige vooraanstaandes aangaan, en teen die helfte van die tydperk ('sewetal') sal hy-die diereoffers en die graanoffers afskaf (9:27).

Elke poging om hierdie 'weke' of 'sewetalle' in terme van $t y d$ te verklaar, stuit op allerlei probleme. In die eskatologies-apokaliptiese konteks van hierdie gedeelte het die 'tydperke' eerder 'n simboliese as reële betekenis

In 10:2 en 3 het "week" die gewone betekenis van sewe dae. Daniël het "drie volle weke" getreur en gevas.

\section{- Maand}

Die derde eenheid van tyd, die maand, kom net in 10:4 voor. Daar is sprake van "die eerste maand", die maand Nisan, ons Maart/April. Die Hebreeuse woord vir 'maand' hier is $\boldsymbol{\emptyset} 7 \pi$, wat ook die betekenis 'nuwe maan' het (Jesus Sirag lê 'n interessante verband tussen 'maan' en 'maand' in 43:6-8). 'n 'Maand' hou dus verband met die maansiklus, en sy duur van 29 dae, 12 uur, 44 minute en 2.8 se- 
kondes word deur die maankalender bepaal (vgl. The American Ephemeris and Nautical Almanac for the Year 1958, p. xvi, aangehaal deur Finegan, 1964:18).

- Jaar

Net soos by Esegiël en Haggai, speel die datering van gebeurtenisse in terme van jare ook in die boek Daniël 'n belangrike rol. Die jaartalle dien veelal om die regeringstyd van onderskeie konings aan te dui $(1: 1,2 ; 2: 1 ; 8: 1 ; 9: 1,2 ; 10: 1$; $11: 1)$. Verder dien jaartalle ook as aanduiding van 'n bepaalde $(1: 5 ; 9: 2)$ of on-

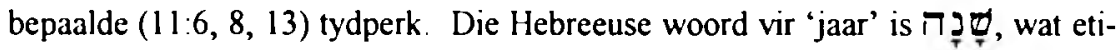
mologies verband hou met die gedagte aan 'verandering', en dan veral toegepas op die verandering van die seisoene (vgl. Finegan, 1964:18-19). In die boek Daniël is geen direkte aanduiding of ons hier met ' $n$ maan- of ' $n$ sonjaar te doen het nie.

\subsubsection{Hebreeuse terme}

Soos ons gesien het, bevat die boek Daniel 'n verskeidenheid Hebreeuse en Aramese

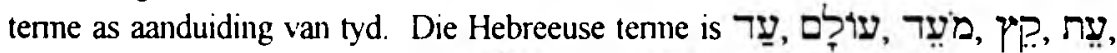

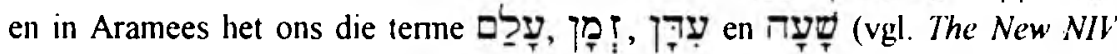
lixhaustive Concordance (Goodrich \& Kohlenberger, 1990) vir wyses waarop dié woorde in die New International Version vertaal word).

- עִ

Die Hebreeuse Ou Testament het geen vaste, beskrywende woord vir 'tyd' nie. Die woord wat die meeste - ongeveer $296 \mathrm{keer}$ - as aanduiding van 'tyd' gebruik word, is עִ Sy afleiding is onseker (kyk Jenni, THAT 2:370-371). Dit is verwant aan die bywoord עִפְת "nou". In die boek Daniël het ook die primêre betekenis van 'tydstip', Engels: point of time, Duits: Zeitpunkt, byvoorbeeld in 9:21: "dit was die tyd van die aandoffer"; 11:24: "maar dit sal van korte duur wees" (letterlik: 'maar net vir 'n tyd'); 12:1: "In daardie tyd"; 12:11: "van die tyd dat die daaglikse offer afgeskaf is."

Die meervoud sluit aan by die betekenis van die enkelvoud. Von Rad (1960:114) wys daarop dat die meervoud vir ons persepsie bloot 'n retoriese hiperbool is, want vir ons is tyd sonder meer tyd. Dit is die rede waarom die meervoud in die nuwe vertaling op sommige plekke gewoon met "tyd" vertaal is, byvoorbeeld: "na verloop van tyd" (letterlik: 'tye') (11:6), "in daardie tyd" (letterlik: 'tye') (11:14). In Hebreeus word nie abstrak oor tyd gedink nie, maar sien die meervoud veelal op gebeurtenisse, omstandighede, ervaringe, op dié dinge wat 'n besondere inhoud aan die "tye" gee (kyk Barr, 1969:123). In die onsekere teks van $9: 25$ is sprake van "tye van verdrukking", "moeilike tye", wat ooreenkom met die 
gebruik van die enkelvoud in 12:1: "Dit sal 'n swaar tyd wees". In sommige gevalle word die afsonderlike tydstippe saamgevat in 'n somtotaal van "tye", wat prakties 'n "tydperk" beteken, byvoorbeeld "in daardie tye" (11:14).

In 'n eskatologiese konteks word بִ 'n aantal kere met perbind, byvoorbeeld "die visioen slaan op die eindtyd" (8:17), "sodat die volk gelouter ... kon word tot die eindtyd toe" $(12: 4,9)$, want "die einde is klaar bepaal" (11:35); "in die eindtyd sal die koning van die suide hom aanval" (11:40; vgl. 11:13). In al hierdie gevalle lê die 'eindtyd' anderkant die geskiedkundige horison, en is dit ' $n$ ongedefinieerde en ondefinieerbare werklikheid.

- p?.?

Dat die gedagte aan die 'eindtyd' 'n belangrike deel van Daniël se prediking vorm, blyk veral uit die veelvuldige gebruik van die woord Yp. ('einde'). Dit kom vyftien keer in hoofstukke $8,9,11$ en 12 voor. Soos ons gesien het, word dit ' $n$ aantal kere saam met עִ verbind om 'die einde van die tyd' aan te dui $(8: 17 ; 11: 35,40 ; 12: 4,9)$. In $11: 13$ word dit saam met die meervoud "tye" gebruik in die betekenis van 'die verloop van ' $n$ aantal tye of jare' (vgl. 11:6). Die 'eindtyd' kom nie maar toevallig nie; dit is vooraf bepaal. Om dit aan te dui,

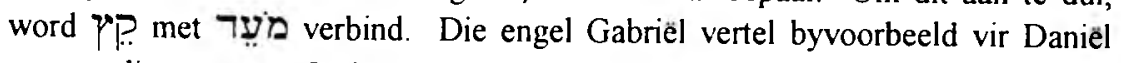
waarop die toorn van God gaan uitloop, en dan sê hy: "Dit gaan oor die eindtyd", letterlik: "die bepaalde tyd van die einde' (8:19). Dieselfde strekking het "einde" in 11:27. Die bose planne van die twee konings sal nie baat nie, "want hulle einde is klaar bepaal". In 9:26 word die woord "einde" eers as onderwerp van die sin gebruik, en dan vorm dit deel van 'n uitspraak: "Die einde sal kom soos 'n oorstroming", en: "daar sal oorlog wees tot die einde toe". Daniël word vermaan om aan te hou "tot die einde toe" (12:13). In 12:6 word gevra: "hoe lank sal hierdie onbegryplike gebeurtenisse nog aanhou", letterlik: "hoe lank voor die einde van die wonderbaarlike dinge'?

\section{- מִעִדר}

Die Hebreeuse woord מִצִ מִ beteken 'afspraak', wat dan toegespits word op of 'n vasgestelde tyd (Engels: an appointed time), of op die plek of feit van 'n ontmoeting. In laasgenoemde geval dui dit veral op die godsdienstige byeenkomste wat deur die kalender of die stand van die hemelliggame bepaal word. In die boek Daniël word dit veral in eersgenoemde betekenis gebruik. Dit gaan om die tyd wat deur God vasgestel is. Dit is die geval met die "eindtyd" $(8: 19 ; 11: 27)$, maar ook met "die bestemde tyd" vir gebeurtenisse om plaas te vind $(11: 29,35)$. In $12: 7$ beteken die uitdrukking wat vertaal is met "die hele vasgestelde tyd", letterlik: 'vir die vasgestelde tyd, die vasgestelde tye en ' $n$ halwe tyd'. In hierdie 
uitdrukking word die toekomsgebeure geperiodiseer en gestel onder die teologiese gesigspunt van die beskikking van God.

\section{עוֹלדם}

Die Hebreeuse woord ער ער sien op die "verste tyd", sowel in die verlede as in die toekoms, en in bepaalde kontekste het dit die betekenis van 'ewig' (vgl. Jenni, THAT 2:228, en Guhrt, NIDNTT 3:827). In die boek Daniël kom laasgenoemde twee betekenisse voor. Die sewentig tydperke wat vir die volk en die heilige stad vasgestel is, sal 'n tyd wees waarin 'n "blywende" geregtigheid tot stand gebring sal word $(9: 24)$. In die grondteks word die meervoud עוֹ עִמים 'blywende' (Engels: everlasting) van die geregtigheid te beklemtoon. Dit veronderstel 'n toestand waarin daar geen einde sal wees nie. Dieselfde gedagte word in 12:3 uitgedruk, waar gesê word dat dié wat baie mense op die regte pad lei "vir altyd" sal skitter soos die sterre. In die oorspronklike word twee sinonieme terme gebruik om die gedagte aan die pernanensie van dié toestand te beklemtoon. Eintlik staan daar: 'vir ewig en altoos' (Engels: for ever and ever). Dit is trouens ook die enigste plek in die boek waar die woord עַ, ('altyd', 'ewig'), voorkom.

Die betekenis van "ewig" in kreatuurlike én absolute sin, kom voor in 12:2 en 12:7. In 12:2 word die eindbestemming van die regverdiges en goddeloses as 'n "ewige" toestand beskryf. Guhrt merk na aanleiding van dié teks op: "From the Book of Daniel onwards 'eternal life' is an expression of the longed-for eschatological blessings of salvation, life in the age to come" (NIDNTT 3:832) en in 12:7 word 'n eed afgelê "by Hom wat ewig lewe". Die 1933-vertaling lui: "by die Ewig-Lewende". Hier word עוֹ עi in sy absolute betekenis van "ewig" gebruik (vgl. ook Hahn, NIDNTT 3:846).

\subsubsection{Aramese terme}

\section{- עָלַם}

Die Aramese vorm עָלָ kom veelvuldig voor, en word gebruik om die koning 'n "baie lang" lewe toe te wens $(2: 4 ; 3: 9,5: 10 ; 6: 7,22)$, om die Naam van God "altyd" (letterlik: 'van ewigheid tot ewigheid') te prys (2:20), om te verklaar dat die koninkryk van God "vir altyd" sal bestaan (2:44), dat dit ' $n$ "ewige koninkryk" sal wees $(4: 3$ [3:33], 34 [31]; 7:14,27), dat die heiliges van die Allerhoogste 'n "ewige koninkryk" sal ontvang (7:18), en veral dat God, wat "ewig leef", geloof en geëer word (4:34 [31]), dat Hy, as die lewende, vir ewig bestaan (6:27). Die woord עָ עָלָ word dus in drieërlei sin gebruik. Dit sien onder andere op die volgende tydsdimensies: 
* 'n lang aardse tyd;

* 'n tydsduur wat verder reik as die aardse tyd, wat na die toekoms dus geen tydsgrens het nie, en

* in pregnante sin op Goddelike ewigheid

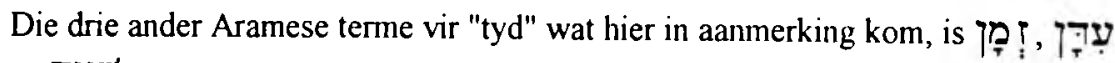

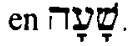

-

Die woord $\prod_{\text {i }}$, in die betekenis van 'n voorgeskrewe of vasgestelde tyd, kom behalwe in die boeke Prediker (3:1), Nehemia (2:6) en Ester $(9: 27,31)$, veral in die Aramese gedeelte van die boek Daniël voor. In 2:16 vra Daniël "uitstel", letterlik: 'dat die koning hom tyd moet gee'. In 2:21 word twee Aramese woorde vir 'tyd' gebruik, albei in die meervoud, en word dit vertaal met: "tye en omstandighede". In 3:7 word p̦ w weergegee met "sodra", letterlik: "in die tyd wanneer', en in 3:8 met die woord "toe", letterlik: 'op daardie tyd'. In 4:33 word gesê dat "op dieselfde oomblik" oor Nebukadnesar gekom het wat oor hom gesê is. Letterlik staan daar 'op daardie tydstip'. In 6:1 l (MT 10) en 6:14 (MT 13) word gesê dat Daniël "drie maal per dag" voor sy God gekniel het. Die woord pị het hier die betekenis van 'geleentheid' (Engels: occurrence). In 7:12 word vertel van die ander diere wie se heerskappy van hulle af weggeneem is, maar wie se lewens nog "'n tyd lank" gespaar is, letterlik: "vir 'n tyd en 'n tyd". Ook hier word twee Aramese woorde vir "tyd" saam gebruik om die feit en aard van die periode te beklemtoon. In 7:22 is מִ מִ die onderwerp van die sin: "Die tyd het aangebreek" dat die heiliges van God die koninklike heerskappy sou ontvang. In 7:25 word die meervoud van daar: 'om tye en wet te verander'. Hier het "tye" die betekenis van 'heilige tye', en daarom kan dit tereg vertaal word met 'godsdienstige geleenthede'.

- עִדיז?

Die Aramese woord עִדָ kom elf keer in die boek Daniël voor, en word in die verskillende kontekste vertaal met "wanneer", "sodra" $(3: 5,15)$, "omstandighede" (2:9), "tye" (2:21), "tydperke" $(4: 16,23,25,32)$. In 7:25 het ons die Aramese ekwiwalent van die Hebreeuse uitdrukking in 12:7: "die hele vasgestelde tyd", letterlik: 'vir 'n tyd en tye en 'n halwe tyd' (vgl. Beek, 1966:19-24). 


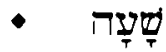

Die vraag of klassieke Hebreeus die woord $u$ ur geken het, word verskillend beantwoord (kyk Beckwith, 1971:218; Gispen, 1957:347; De Vries, 1975:38, Barr, 1969:107). Die feit is dat dit nie in die Hebreeuse gedeeltes van die Ou Testament voorkom nie (vgl. Smick, 1976:1710). Ons vind dit wel in Bybelse Aramees, en wel op vyf plekke in die boek Daniël. In dié gedeeltes word die woord שִָָׁ vertaal met "onmiddellik" (letterlik: 'in dieselfde uur') (3:6), "dadelik" (3: 15), "'n oomblik" (4:19), "op dieselfde oomblik" (4:33), en "meteens" (5:5; kyk Finegan, 1964:11).

\section{- Konklusies}

'n Oorsig van die verskillende aanduidings van tyd in die boek Daniël, lei tot die volgende konklusies:

Dit is opvallend hoe veelvuldig in die boek na 'tyd' verwys word. Feitlik al die belangrikste Hebreeuse én Aramese woorde vir 'tyd' word in allerlei kontekste gebruik.

Hierdie feit is van die grootste belang vir sowel die verlaling as die verklaring van die boek. Die vertaling kan nie volstaan met 'n blote leksikografiese weergawe van die betekenis van die afsonderlike woorde nie, maar moet steeds fyn onderskei tussen die verskillende nuanses van betekenis in die betrokke kontekste. Die verklaring weer sal rekening moet hou met die historiese en die eskatologies-apokaliptiese perspektiewe wat die onderskeie terme op die inhoud van die boek open.

Die moderne tendens by sommige geleerdes is om die rekonstruksie van die historiese agtergrond veral van profetiese boeke as onmoontlik te beskou. Hierdie negatiewe benadering van die historiese moment was onder meer duidelik in sommige referate wat gelewer is op "The Old Mutual Symposium on Contextual Bible translation", 13-17 September 1993 op Stellenbosch. Ek stem egter saam met Philip A. Noss (1993:309-310) se opmerking:

In any succesful piece of literary art, time is a prominent feature. Whether it is the author's relation to time in his narrative, his use of time as a structural or literary device, or his treatment of time as a theme, the element of time is a major component of literary art.

Hy pas dit sinvol toe op die samestelling en boodskap van die boek Ester, maar dit kan net so goed toegepas word op ander Bybelboeke, soos Jeremia, Esegiël, Haggai, Sagaria en op Daniel. Soos ons gesien het, speel die tydsfaktor in die boek Daniël 'n deurslaggewende rol. 
Die swaar klem wat in die boek op die "eindtyd" in terme van die woorde ppe en

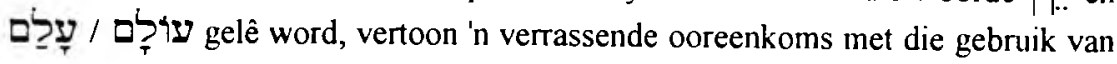
die terme in die Qumran-geskrifte en by die latere Rabbyne ( $\mathrm{vgl}$. Jenni, THAT 2:242-243; Preuss, 1986:242-243 artikel עוֹ עi en Barr, 1969:124-125). Hierdie opvallende ooreenkomste mag 'n bykomende oorweging wees om die ontstaan van die boek Daniël in die tweede eeu v.C. te dateer.

Teologies belangrik is die gesigspunt dat die "tyd" en "tye" in die boek Danië] deur God bepaal en vasgestel is, soos veral blyk uit die gebruik van die woord

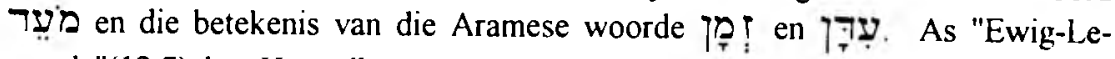
wende"(12:7) het Hy volkome en soewereine beheer oor die voortwentelende eeue, tot aan die "einde" toe.

By die wisseling van ons kollega en vriend se "tye", mag hy vir seker weet dat ook sy "tye" in God se hand is (Ps. 31:16).

\section{Aangehaalde bronne}

BARR, J 1969. Biblical Words for Time. London: SCM Press

BECKWITH, ROGER T. 1971. The Day, Its Divisions and Its Limits in Biblical Thought. Evangelical Quarterly, 43:218-227.

BEEK, M.A 1966. Zeit, Zeiten und eine halbe Zeit (In Van Unnik, W C. \& Van der Woude, A S. Studia Biblica et Semitica, Th C. Vriezen dedicata Wageningen : Veenman en Zonen. p. 19-24)

DE VRIES, S J. 1975. Yesterday, Today, and Tomorrow. Time and History in the Old Testament Grand Rapids/London : Society for Promoting Christian Knowledge

FINEGAN, J. 1964 Handbook of Biblical Chronology: Principles of Time Reckoning in the Ancient World and Problems of Chronology in the Bible Princeton : University Press

GISPEN, W.H. 1957. Dag. (In Gcosheide F.W. \& Van Itterzon, G P Christelijke Encyclopedie Kampen : Kok p. 347.)

GOODRICH, E.W \& KOHLENBERGER, J R., ed 1990 The New NIV Exhaustive Concordance. Grand Rapids : Zondervan Publishing House.

GUHRT, J 1978 ( $n$ Brown, C ed The New International Dictionary of New Testament Theology 3:826-833.)

HAAG, E. 1989 1989. 'ad (In Botterweck, et al Theologishes Worterbuch zum Alten Testament. 5: 1066-1074.)

HAHN, H -C 1978. (In Brown, C. ed The New International Dictionary of New Testament Theology 3:833-849.)

JENNI, E. 1962. Time The Interpreter's Dictionary of the Bible 4:642-649

JENNI, E. 1976 Verskillende artikels. (In Jenni, E. \& Westermann, C. eds., Theologisches Handwörterbuch zum Atten Testament. München : Chr. Kaiser Verlag 22 207-209, 228 243, 370-385.)

KRONHOLM, T. 1989. עת (In Botterweck, et al. Theologisches Worterbuch zum Alten Testament, 6:463-482.)

LOUW, JP \& NIDA, E A 1988 Greek-English Lexicon of the New Testament based on Semantic Domains. New York : United Bible Societies 1:628-629 
NIDNTT $=$ The New International Dictionary of New Testament Theology $k$.k

BROWN, C ed. 1975. The New International Dictionary of New Testament Theology Exeter : Patenoster Press.

NILSSON, M.P. 1960. A Study in the Origins and First Development of the Art of Counting Time among the Primitive and Early Culture Peoples (2d ed) Lund : C.W.K Gleerup

NOSS, PA 1993 A Footnote on Time: the Book of Esther The Bible Translator. 44(3) $309-320$.

PREUSS, HD 1986. עוֹרִם (In Botterweck et al. Theologisches Wörterbuch zum Alten Testament, 5:1144-1159.)

SMICK, Elmer B. 1976. (In Pfeiffer, Charles F. el al ed, Wycliffe Bible Encyclopedia Chicago : Moody Press p 1710.)

SPIER, J.M 1953. Tijd en eeuwigheid. Een wijsgerig onderzoek bij het licht van Gods Woord. Kampen : Kok

STROES, HR 1966 Does the Day begin in the Evening or Morning letus Testamentum. 16:460-475

THAT $=$ Theologisches Handworterbuch zum Alten Testament Munchen : Chr Kaiser Verlag $k y k$

JENNI, E \& WESTERMANN, C eds. 1976 Theologisches Handworterbuch zum Alten Testament. Munchen : Chr Kaiser Verlag

VON ORELLI, C 1871 Die hebraischen Synonyma der Zeit und Ewigkeit genetisch und sprachvergleichend dargestellt. Leipzig : A. Lorentz

VON RAD, G. 1960. Theologie des Alten Testaments Munchen : Kaiser 2:112-125

\section{Geraadpleegde bronne}

DE VRIES, S J 1962. Day. The Interpreter's Dictionary of the Bible. New York Abingdon Press. I: 783.

HASEL, G.F 1979. Day, etc (In Bromiley, G W, ed International Standard Bible Encyclopedia 1 Grand Rapids : Eerdmans p. 876-879.)

MARTI, K 1899 Day. Encyclopaedia Biblica Cheyne, T K ed London Adam \& Charles Black. 1:1033-1038

MUILENBURG, J 1961 The Biblical View of Time Hariard Theological Studies, 54225 271

NILSSON, M P 1960. A Study in the Origins and First Development of the Art of Counting Time among the Primitive and Early Culture Peoples ( $2 \mathrm{~d} \mathrm{ed}$ ). Lund C.W.K Gleerup

SAEBO, M, et al. 1982 ירם (In Theologisches Worterbuch zum Alten Testament, 3.566586.)

VAN MIERLO, S. 1963 De oude kalender bij de Hebreeen en zijn verband met de lijdensweek Kampen : Kok 
